\title{
FEATURE Cheatgrass invasion and woody species encroachment in the Great Basin: Benefits of conservation
}

\author{
Mark A. Weltz, Ken Spaeth, Michael H. Taylor, Kimberly Rollins, Fred Pierson, Leonard Jolley,
} Mark Nearing, Dave Goodrich, Mariano Hernandez, Sayjro K. Nouwakpo, and Colleen Rossi

$\mathrm{T}$ he Great Basin is the largest North American desert, covering more than 49.6 million ha (122.5 million ac), and includes most of Nevada, a large part of Utah, and smaller sections of Oregon, Idaho, and California. Two of the biggest threats to ecosystem stability and integrity in the Great Basin are invasive annual grasses, particularly cheatgrass (Bromus tectorum L.), and expansion of native woody plants, particularly juniper (Juniperus spp.) species and pinyon pines (Pinus monophylla Torr. and Frém. and Pinus edulis Engelm.). An estimated 72\% (36 million ha [88 million ac]) of the Great Basin is currently impacted by cheatgrass (Pellant et al. 2004). Pinyon and juniper woodlands currently occupy approximately 22.5 million ha $(55.6$ million ac) throughout the western United States (Miller et al. 2011). In the Great Basin alone, the occupied area is nearly 7.1 million ha (17.5 million ac), the result of a $125 \%$ to $625 \%$ increase in tree distribution, much of which occurred in areas where these species were not inherent components of the plant community (Miller et al. 2008).

The alteration of native plant communities by these invasive species can increase the likelihood of damaging and dangerous wildfires that change the hydrologic system and degrade soil health and quality (Pierson et al. 2011; Miller et al. 2013). Cheatgrass invasion has led to shorter wildfire return intervals on Great Basin rangelands in the period from

Mark A. Weltz is a rangeland hydrologist for the USDA Agricultural Research Service in Reno, Nevada. Ken Spaeth is a rangeland hydrologist for the USDA Natural Resources Conservation Service, Fort Worth, Texas. Michael H. Taylor and Kimberly Rollins are economists for the University of Nevada Reno, Reno, Nevada. Fred Pierson is a rangeland hydrologist with the USDA Agricultural Research Service, Boise, Idaho. Leonard Jolley is a rangeland ecologist for the USDA Natural Resources Conservation Service, Napa, California (retired). Mark Nearing and Dave Goodrich are agricultural engineers with the USDA Agricultural Research Service, Tucson, Arizona. Mariano Hernandez is a hydrologist with University of Arizona, Tucson, Arizona. Sayjro K. Nouwakpo is a soil scientist with the University of Nevada Reno, Reno, Nevada. Colleen Rossi is a soil scientist with the Bureau of Land Management, Denver, Colorado.
1980 to 2009, with cheatgrass-dominated land four times more likely to burn than any native vegetation type during the 1990s (Balch et al. 2013). Balch et al. (2003) estimated an average wildfire return interval of 78 years for cheatgrass-dominated rangeland. The continued infilling of pinyon and juniper increases woody fuel loads and risk of high severity stand-replacing wildfires (Romme et al. 2009). As a result of higher fuel loads in dense pinyon and juniper stands, when fires do occur they are more severe, opening the landscape to introduction of invasive species (Miller et al. 2008). Between 2000 and 2009, 6.6 million ha (16.2 million ac) burned in the Great Basin. Of these 6.6 million ha, approximately 0.8 million ha (2 million ac) reburned due to the emergence of a cheatgrass fire cycle on invaded rangelands.

The immediate costs of large wild land fires can exceed US $\$ 20$ million (Running 2006), but economic impacts extend beyond control of wildfires. Billions of dollars have been spent on wildfire suppression, and millions have been spent on postfire mitigation over the last decade (Stockmann et al. 2010). Intense rainstorms after wildfires may cause flooding and extensive soil erosion (figure 1). The focus of our article is to illustrate how Ecological Site Descriptions (ESDs) can be used to guide conservation. The article discusses the economic and environmental benefits of conservation on rangelands and provides examples of how conservation can reduce costs associated with wildfire while also enhancing soil and water benefits.

\section{ECOLOGICAL THEORY}

Modern ecological theory has changed from a concept of climax-based linear succession and retrogression (Dyksterhuis 1949) to ESDs that incorporate concepts of state and transitions models (STM), thresholds, resilience, and multiple stable plant communities (Bestelmeyer and Briske 2012). The concept of ESD is now the principal method of organizing and describing rangeland plant communities in the United States (Brown 2010). The shift to ESD theory has contributed to the development of concepts to address resilience-based management and has provided land managers

\section{Figure 1}

(a) Great Basin pinyon and juniper woodland near Gardnerville, Nevada, illustrating rill erosion, (b) channel erosion and deposition in first order channel, and (c) scoured channel with extensive bed load deposits in main stream channel following a single rainstorm four months after a wildfire. These photographs illustrate the vulnerability to accelerated soil erosion for these woodlands sites if the sites are not successfully revegetated the first year following a fire (photographs by Christo Morris, Eastern Oregon University, LaGrange, Oregon).

(a)

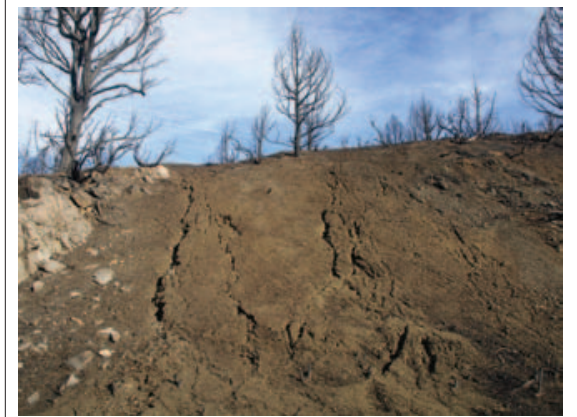

(b)

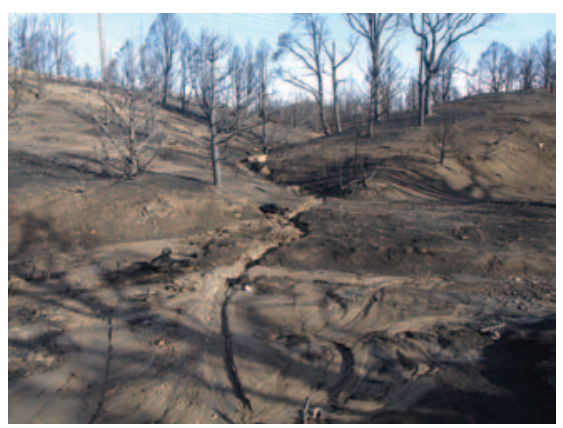

(c)

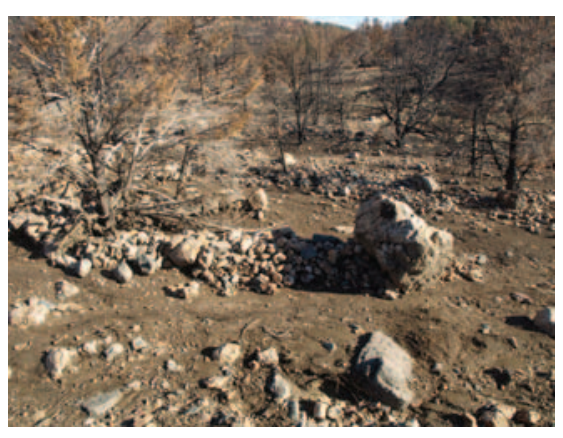


a standardized method of managing rangelands and evaluating ecosystem health (Pellant et al. 2005). State and transition models in ESDs are designed to address resilience-based management, incorporate ecological feedbacks that affect transiting from one state to another, and estimate the impact/response of rangeland conservation practices (Bestelmeyer et al. 2009).

Tidwell et al. (2103) in their review of ESDs and STMs concluded that STMs are mostly conceptual, built on expert opinion, have not been uniformly developed, and have not been scientifically evaluated to determine if the proposed cause-and-effect changes in plant communities provided in the STMs are accurate and achievable. This critique notwithstanding, the modern paradigm of assessing rangeland ecosystems through ESDs, STMs, and rangeland health is an improvement over the historic range site monoclimax approach. ESDs are evolving over time, and as the second generation of ESDs is developed based on scientific experimentation, the utility of this approach will be enhanced to assist land managers in monitoring and assessing ecosystem health and targeting conservation practice selection (Brown 2010).

Wyoming Sagebrush State and Transition Models. According to Tamzen Stringham (personal communication, August 23, 2013), The Natural Resources Conservation Service (NRCS), Bureau of Land Management, and University of Nevada Reno partners are currently developing new STMs for sagebrush-dominated systems within Nevada using a Disturbance Response Group (DRG) approach. The DRG approach aggregates similar ESDs that will respond to a disturbance, such as fire, into a functional STM that makes postfire emergency management decisions more efficient than developing individual response plans by ecological site. Figure 2 depicts a much stylized description of three of the six ecological states of the proposed loamy 20 to $25 \mathrm{~cm}$ (8 to $10 \mathrm{in}$ ) precipitation zone STM. Current potential state (WSS1) is dominated by Wyoming sagebrush (Artemisia tridentata ssp. wyomingensis Beetle and Young), native grass and forbs, and nonnative annual species maybe present within the site. Sagebrush-bluegrass state (WSS2) has decadent Wyoming sagebrush and/ or rabbitbrush (Ericameria nauseosa [Pall. ex
Pursh] G.L. Nesom and Baird) that dominate the overstory, and Sandberg's bluegrass (Poa secunda J. Presl) dominates the understory. Annual grasses have increased, and junipers may be present or increasing on the site. The annual plant state (WSS-3) is dominated by cheatgrass and tansy mustard (Descurainia pinnata [Walter] Britton).

Management Options to Transition between Wyoming Sagebrush States. Improper grazing removes native grasses and forbs from the interspace and can increase bare ground (Chambers et al. 2013). Improper grazing may alter the hydrology of the system by exposing more bare ground, decreasing water infiltration, and promoting increased water and wind erosion (Miller et al. 2013). Unchecked, improper grazing can degrade a WSS-1 state into a WSS-2 state. This new state can have a shorter 75-year wildfire return interval if cheatgrass has filled in open spaces between the Wyoming sagebrush plants (Limbach 2011). The probability of a wildfire occurring in WSS-2 is greatest during a drought, when plant materials are desiccated and high winds are present to carry the fire across the depopulate interspaces. Appropriate management (grass and forb reseeding, brush management, prescribed grazing, and wildfire suppression) has the potential to reverse the degradation and return aWSS-2 site to WSS-1 state. Once the system has transitioned to WSS-3 state, however, it has crossed an ecological threshold from which it is nearly impossible to restore

\section{Figure 2}

Economic cost of treatment for alternative states within a Wyoming sagebrush plant community (WSS) $(1,400$ to $2,000 \mathrm{~m})$.

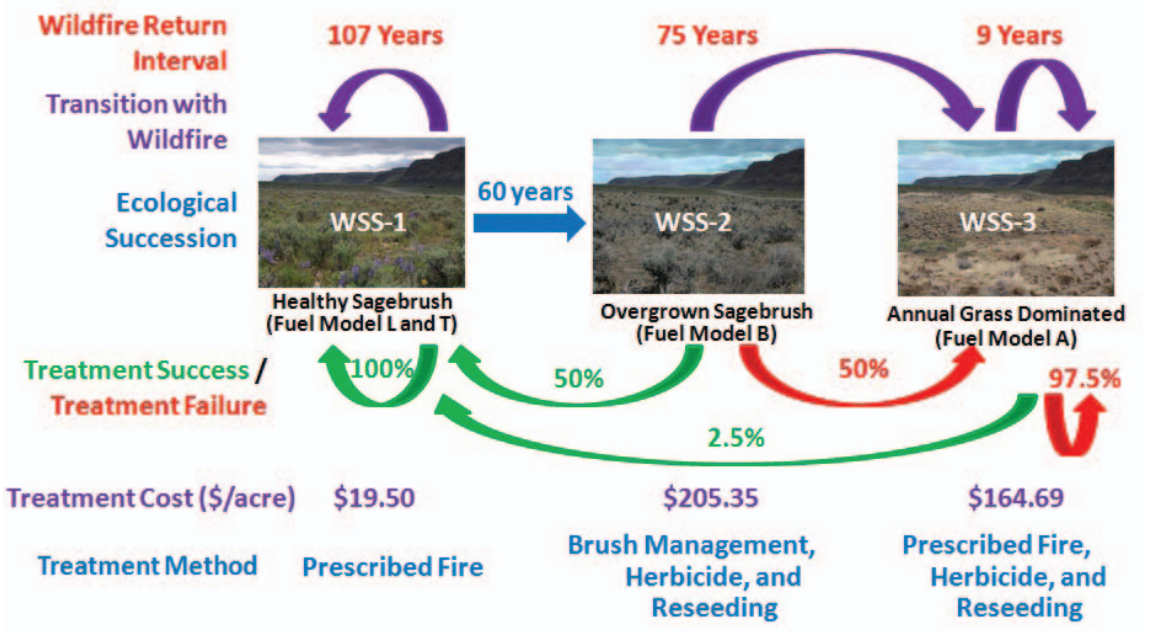

to a WSS-1 state even with significant conservation investments (Chambers et al. 2013).

Mountain Sagebrush State and Transition Models. The current working DRG model for loamy slope 30 to $41 \mathrm{~cm}$ (12 to 16 in) precipitation zone STM model has five states and community phases. Within each state, multiple plant communities may exist depending on historic disturbance, management, and recent climate (Miller et al. 2013). Figure 3 presents a generalized description of selective mountain big sagebrush DRG states for three of the five ecological states. Current potential state (MBS-1a) is dominated by mountain big sagebrush (Artemisia tridentata Nutt. ssp. vaseyana [Rydb.] Beetle), native and nonnative grasses, and forbs. In the sagebrush-Sandburg bluegrass state (MBS-1b), mountain big sagebrush and rabbitbrush have increased and dominate the overstory, Sandberg's bluegrass dominates the understory, annual nonnative species are present, and pinyon pine and Utah juniper (Juniperus osteosperma [Torr.] Little) may be present and encroaching on the site. Tree-invaded state (MBS-2) is defined as sites encroached upon by Utah juniper and/or pinyon pine, and mountain big sagebrush is a minor component. Native grasses may be present but are declining, and annual grasses may codominate the understory. Annual plant dominated state (MBS-3) is dominated by cheatgrass and tansy mustard.

Management Options to Transition between Mountain Sagebrush States. The MBS-1a is a high-altitude sagebrush com- 
munity with a 60-year wildfire return interval (Major et al. 2011). The MBS-1a state may shift to another state in which immature conifers and sagebrush coexist (MBS-1b). Low-intensity, prescribed fires can remove conifer seedlings, but fire may injure desired species. Brush management and seeding of desired species can return the MBS-1b state to the MBS-1a state. Without management, intervention conifers mature and dominate the site. Improper grazing and/or decreased fire frequencies may drive the MBS-1b system across an ecological threshold wherein conifers mature and the canopy closes (MBS-2) (Miller et al. 2013). Returning a MBS-2 state to a MBS-1a state is more difficult than transitioning an MBS-1b back to MBS-1a state. When fires do occur, they tend to be high-intensity crown fires that kill both conifers and native shrubs. Mechanical treatments are generally used to treat closed canopy conifer systems. Exotic annual grasses are highly adapted to capitalize on any form of disturbance, and cheatgrass may quickly dominate inappropriately managed MBS-2 states, transitioning them to a low diversity MBS-3 state. Restoration pathways from MBS-2 state to MSB-1a are thought possible only through intensive and costly restoration treatments. The probability of restoration success is strongly influenced by the degree to which residual native understory plants have been retained in the system. Successful restoration from MSB-3 to MSB-1a is unlikely with current knowledge, plant materials, and techniques.

\section{ECONOMIC BENEFITS OF CONSERVATION: WILDFIRE SUPPRESSION COST SAVINGS}

As is discussed in detail in the previous two sections, invasive annual grasses and encroachment by woody plants adversely impact several rangeland ecosystem services. The economic benefits of conservation can be measured by the extent that conservation restores and/or maintains ecosystem services as a result of invasive plants. In a recent study, Taylor et al. (2013) adopt this approach and estimate the economic benefits from prefire conservation practices (fuel treatments) for the Wyoming sagebrush steppe and mountain big sagebrush plant communities as the difference in the expected net present value of wildfire suppression with and without treatment. These estimates account for both (1) how wildfire influences ecological change in rangeland ecosystems where invasive plants are present and (2) how changes in state as a consequence of annual grasses and woody plants influences the frequency and intensity of wildfire, and the cost of wildfire suppression.

Wildfire suppression costs, wildfire probabilities, and fuel management treatment costs in Taylor et al. (2013) vary with state in the Wyoming sagebrush steppe and

\section{Figure 3}

Economic cost of treatment for alternative states in a mountain sagebrush plant community $(>2,000 \mathrm{~m})$.

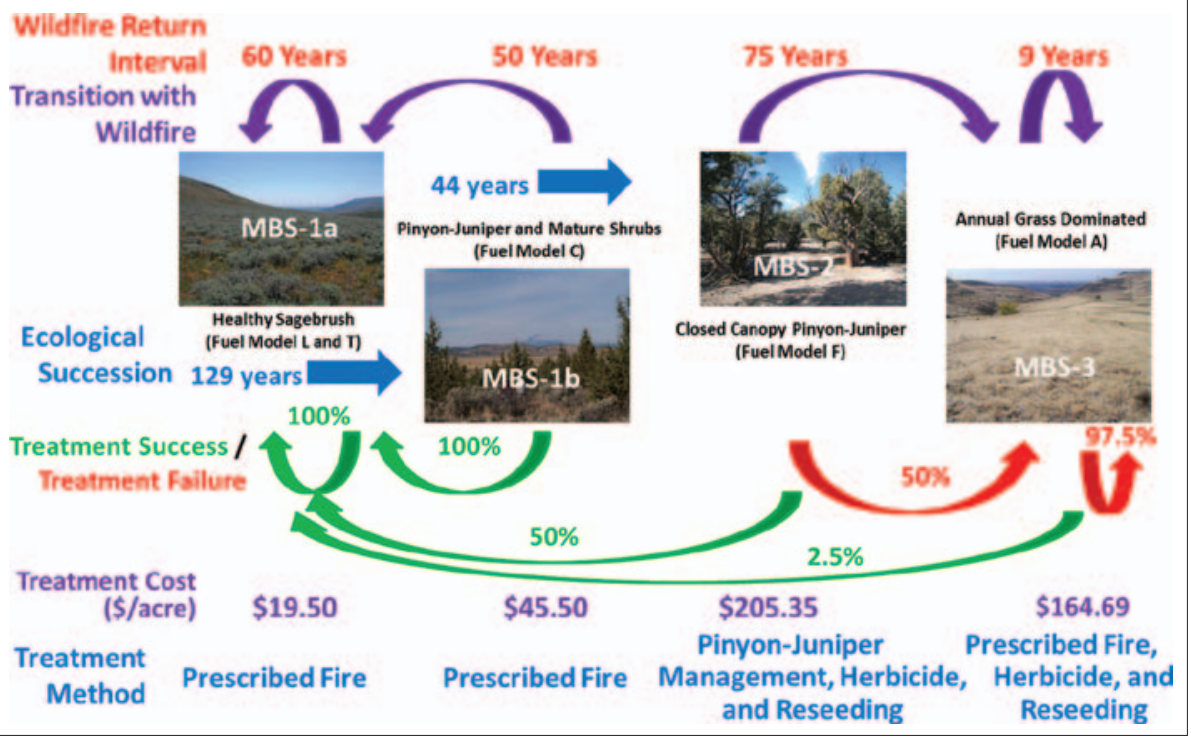

mountain big sagebrush ecosystems. The wildfire suppression costs in each state were obtained from data on 400 wildfires occurring from 1995 through 2007 in US Forest Service Region 4 (the Intermountain Region, which includes Wyoming, Utah, Idaho, Nevada, and portions of Colorado and California). Wildfire return intervals and times for ecological transition between states specific to the Wyoming sagebrush steppe and mountain big sagebrush systems were obtained through the US Forest Service's LANDFIRE rapid assessment vegetation model. Per-acre costs for the fuel treatments (e.g., herbicide treatments, reseeding, prescribed fire, and mechanical brush removal) were obtained from the 2011 NRCS conservation practice cost data. NRCS conservation practice cost data is used to determine payment rates from the Agricultural Management Assistance program, the Environmental Quality Incentives Program, and the Wildlife Habitat Incentives Program for western states, including Utah and Nevada.

For Wyoming sagebrush steppe communities, Taylor et al. (2013) found that fuel treatment is economically justified in terms of wildfire suppression cost savings only before cheatgrass has become established. Fuel treatments have expected net benefits in terms of wildfire suppression costs averted of US\$672.13 $\mathrm{ha}^{-1}$ (US\$272 $\mathrm{ac}^{-1}$ ) for WSS-1 (table 1). In contrast, fuel treatment costs exceed wildfire suppression cost savings in the two degraded ecological states (WSS-2 and WSS-3). They evaluated the sensitivity of these results to the assumptions about conservation treatment success rates in WSS-2 and WSS-3 (the baseline treatment success rates in their simulation are $50 \%$ in WSS-2 and 2.5\% in WSS-3). Taylor et al. (2013) reported that in WSS-2 treatment is economically efficient for success rates of $75 \%$ or higher at the default treatment cost of US $\$ 507.43 \mathrm{ha}^{-1}$ (US $\$ 205.35$ $\mathrm{ac}^{-1}$ ) and that treatment in WSS-3 is economically efficient for success rates of $52 \%$ or higher at the default cost of US $\$ 406.96$ $\mathrm{ha}^{-1}$ (US\$164.69 $\mathrm{ac}^{-1}$ ). Improved treatment success rates might be attained through alternative treatment methods, increasing the application intensity, or by applying the results of new scientific research aimed at increasing effectiveness. 


\section{Table 1}

Wyoming sagebrush and mountain sagebrush plant community results for fuel load reduction treatments (US\$ ac ${ }^{-1}$ in 2010 dollars; Net Present Value (NPV) over 200 years; $3 \%$ rate of discount).

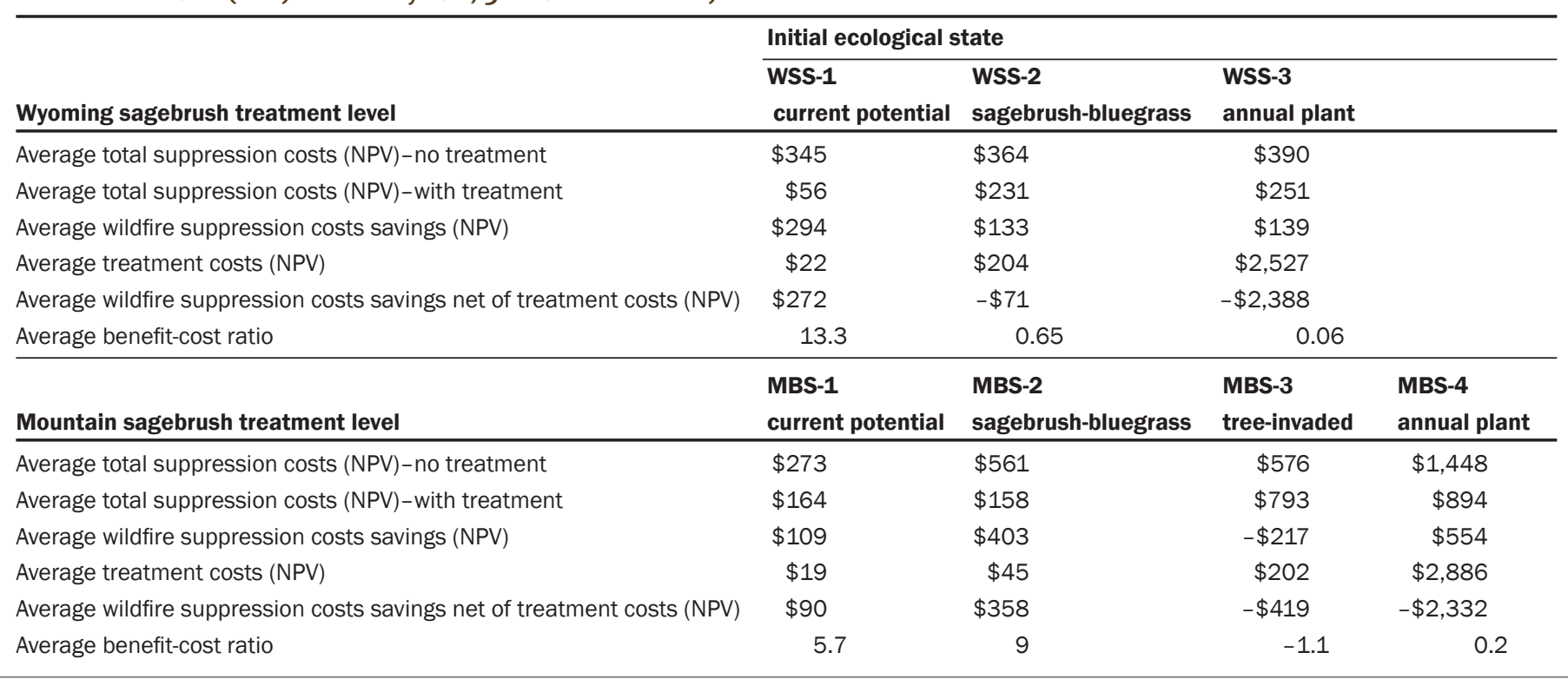

In the mountain big sagebrush system, the expected net benefits of treatment are small but positive in MBS-1a state (US\$222.39 $\mathrm{ha}^{-1}$ [US\$90 $\mathrm{ac}^{-1}$ ]) and are largest in MBS-1b, the early stages of pinyon-juniper expansion (US\$884.64 ha $\mathrm{ha}^{-1}$ [US\$358 ac $\mathrm{ac}^{-1}$ ) (table 1). Fuel treatments are not cost effective in the two degraded ecological states (MSB-2 and MSB$3)$. In the MBS-2, the closed-canopy woody plant state, average wildfire suppression costs are higher with fuel treatment than without. This counterintuitive result is due to the possibility of treatment failure in MBS-2.Treatment failure in MBS-2 results in the systems transitioning to MBS-3, the annual grass-dominated state, which entails more frequent wildfire and higher wildfire suppression costs. Because of the high cost of treatment failure in MBS-2, average wildfire suppression costs are lower if the lands remain untreated, even though the system may eventually transition to MBS-3 after a natural occurring wildfire.

The consequences of pinyon-juniper expansion, cheatgrass invasion, and increasing fire frequency are not only ecological, but socioeconomic as well. As intervals between wildfires shorten because of annual grass invasion, prefire suppression treatments may well become cost effective in the WSS-2 state. Results in Taylor et al. (2013) indicate that treatment is economically efficient in WSS-2 for wildfire return intervals of 50 years or shorter.

\section{ENVIRONMENTAL BENEFITS OF CONSERVATION: REDUCED WATER EROSION}

The USDA Rangeland Hydrology and Erosion Model (RHEM) (Nearing et al. 2011) was used to estimate the impact of changing from one state to another for two different plant community types (Wyoming sagebrush and mountain sagebrush) to estimate soil and water benefits from conservation. RHEM is parameterized based on plant growth form classification (e.g., shrub to grass or shrub to annual grass) using the data that is typically collected for monitoring rangelands (NRCS National Resources Inventory [NRI]), which makes it suitable for estimating benefits of moving between different states within an ESD.The CLIGEN model (Nicks et al. 1995) was run to provide 300 years of daily precipitation records for input into RHEM. If runoff occurred, soil erosion was estimated for that day. The RHEM outputs were analyzed to provide estimates of the 2-, 10-, and 50-year return period runoff events and the vulnerability of the site to accelerated soil loss using techniques described by Weltz and Spaeth (2012).

For a typical Wyoming sagebrush site at current potential near Austin, Nevada, waterinduced soil loss was 2.4 to 3 times lower than it was on a burned site previously dominated by cheatgrass (table 2). In addition to greater soil loss, the burned cheatgrass site had 1.2 to
1.6 times more runoff during intense summer thunderstorms. This additional runoff could lead to increased downstream flooding and reduces available soil moisture essential for successful revegetation of postfire areas. Runoff and soil loss from a cheatgrass dominated site was estimated to be slightly elevated over the current potential site (table 2). The actual impact of a site being converted to cheatgrass will depend on the difference in canopy and ground cover between the sites and likely will vary annually depending on climate, which will determine annual plant productivity, canopy, and ground cover.

Wilcox et al. (2012) modeled the response to cheatgrass invasion and predicted an increase in runoff and erosion on native sagebrush communities when slopes exceeded 15\% and cover was <80\%. Meyer et al. (2001) reported numerous hill slope failures during a natural rainfall event on degraded cheatgrass-dominated rangelands resulting in extensive soil loss. Hernandez et al. (2013) reported that RHEM could effectively assess the influence of foliar, ground cover, plant life-form, soils, and topography on current soil erosion rates using data from NRCS NRI on-site data collection in southern Arizona.

RHEM predicted soil erosion increases of nearly 10-fold following wildfire on mountain sagebrush sites (table 2). After a wildfire, runoff may increase by 4 -fold, 


\section{Table 2}

Plant community, site attributes, and Rangeland Hydrology and Erosion Model-modeled hydrologic response of a Wyoming sagebrush plant community near Austin, Nevada, and a mountainbig sagebrush plant community near Elko, Nevada.

\begin{tabular}{|c|c|c|c|c|c|c|}
\hline \multirow{2}{*}{$\begin{array}{l}\text { Site attribute or } \\
\text { hydrologic response }\end{array}$} & \multicolumn{3}{|c|}{ Wyoming sagebrush site } & \multicolumn{3}{|c|}{ Mountain sagebrush site } \\
\hline & Current potential & Annual plant & Burned annual plant & Current potential & Juniper tree & Burned juniper tree \\
\hline Slope (\%) & 20 & 20 & 20 & 30 & 30 & 30 \\
\hline Soil texture & Sandy clay loam & Sandy clay loam & Sandy clay loam & Sandy loam & Sandy loam & Sandy loam \\
\hline Canopy cover (\%) & 30 & 25 & 0 & 50 & 50 & 0 \\
\hline Basal cover (\%) & 8 & 5 & 0 & 12 & 7 & 0 \\
\hline Cryptogams cover (\%) & 2 & 0 & 0 & 20 & 0 & 0 \\
\hline \multicolumn{7}{|l|}{ 2-year storm } \\
\hline Rainfall (mm) & 25.6 & 25.6 & 25.6 & 19.1 & 19.1 & 19.1 \\
\hline Runoff (mm) & 6.76 & 9.02 & 11.09 & 1.77 & 3.64 & 6.87 \\
\hline Soil loss $\left(\operatorname{tn~ac}^{-1}\right)$ & 0.11 & 0.17 & 0.33 & 0.03 & 0.06 & 0.28 \\
\hline Soil loss (tn ac ${ }^{-1}$ ) & 0.4 & 0.56 & 0.98 & 0.17 & 0.25 & 0.79 \\
\hline \multicolumn{7}{|l|}{ 50-year storm } \\
\hline Rainfall (mm) & 52.7 & 52.7 & 52.7 & 43.3 & 43.3 & 43.3 \\
\hline Runoff (mm) & 30.91 & 33.52 & 36.76 & 22.95 & 28.1 & 29.43 \\
\hline Soil loss (tn $\mathrm{ac}^{-1}$ ) & 0.79 & 1.08 & 1.88 & 0.45 & 0.71 & 1.7 \\
\hline
\end{tabular}

depending on storm intensity, and raise the probability of downstream floods from burned mountain sagebrush sites. RHEM predicted increases in both runoff and sediment yield where the site had been encroached by pinyon and juniper trees above that for a site in current potential. These results are consistent with those reported by others that sites encroached by pinyon and juniper trees, both prefire and postfire, have increased potential for runoff and accelerated soil erosion (Pierson et al. 2011, 2013). Weltz and Spaeth (2012) used RHEM to assess the impact of ecological sites invaded with Ash juniper (Juniperus ashei J. Buchholz), on the Edwards Plateau near Johnson City, Texas. They determined that applying conservation to return the invaded site to reference conditions could reduce soil loss by up to 6-fold depending on the runoff return period evaluated.

In mountain sagebrush sites that have been encroached by pinyon and juniper trees, the type and distribution of canopy and ground cover are altered relative to the current potential state. In the current potential state, more uniformly distributed vegetation makes concentrated flows unlikely and minimizes soil loss and runoff. When pinyon and juniper trees invade and canopy closure advances, the understory cover (grasses and forbs) declines and bare soil increases (Davenport et al. 1998). This further increases the probability of concentrated flows in the connected bare spaces and results in accelerated runoff and soil erosion (Pierson et al. 2013). Appropriate use of mechanical treatments to remove pinyon and juniper trees can return an encroached site to current potential state and reduce soil erosion and threat of wildfire. The degree to which fire increases runoff and erosion from Great Basin rangelands is determined by burn severity (amount of vegetation and ground cover removed); inherent ecological site characteristics, such as soil depth, slope steepness and length; and the intensity and duration of the precipitation event.

RHEM-estimated runoff and soil loss rate results from Wyoming and mountain sagebrush sites are consistent to that reported by others in that sites dominated by cheatgrass or burned cheatgrass sites can result in increased risk of soil erosion and runoff (Meyer et al. 2001). The results presented here indicate that RHEM can be used to assess the relative erosion rates on rangelands and that RHEM can be used to assess the potential soil and water benefits from applying conservation and tran- sitioning from one ecological state to another. Monitoring programs, such as NRCS NRI onsite data, combined with modeling can enable more effective targeting of conservation dollars to maximize environmental and economic benefits (Doering et al. 2013). Use of ESDs and STMs in conjunction with modeling of prevention of wildfires and associated soil erosion based on quantitative data such as that from rangeland NRI can be used to predict the effectiveness of alternative management actions and support cost-benefit analyses to optimize return on investment in conservation. The spatially unbiased nature of the rangeland NRI assessment in conjunction with use of ESDs and STMs allows for rapid determination of regional needs and identification of where conservation may be most cost effective in minimizing land degradation from wildfires and invasive weeds.

\section{SUMMARY AND CONCLUSIONS}

Relatively few studies have estimated the economic benefits of conservation for rangeland systems threatened by invasive annual grasses or invasive woody plants. Recent studies have integrated rangeland STMs into economic-ecological simulation models and used these integrated models to estimate the 
benefits of conservation in terms of wildfire suppression costs savings (Epanchin-Neill et al. 2009; Taylor et al. 2013). By considering wildfire suppression cost savings and ignoring other ecosystem services, these studies necessarily understate the economic benefits of conservation. In order to provide a full-accounting of the economic benefits of conservation on rangeland that is threatened by invasive plants, further research is needed to quantify how ecosystem services, such as wildlife habitat, forage for livestock, recreation opportunities, and erosion control, change as a consequence of annual grass invasion and woody plant encroachment.

Given current and impending economic impacts of the intertwined invasive plant and wildfire cycle on private and public lands across the West, large landscape-scale adaptive management approaches are needed to impede exotic annual grass and native tree species expansion before entire landscapes are degraded and destabilized. Unfortunately, few conventional cheatgrass eradication methods have been shown to be effective or practical for widespread application. The most cost-effective conservation is prevention, i.e., the early detection and eradication of exotic annual grasses such as cheatgrass. Additional research on cost-effective conservation and management measures to prevent expansion of cheatgrass and pinyon and juniper woodlands and reduce damages where it is already established is needed to protect and enhance rangeland ecosystem services.

\section{ACKNOWLEDGEMENTS}

We thank Laura Weltz, geographical information specialist and USDA Agricultural Research Service volunteer, Reno, Nevada, for assisting with data analysis and Christo Morris, instructor, Oregon State University Program at Eastern Oregon University, LaGrange, Oregon, for supplying photographs of soil erosion. Support for this research was provided by the USDA Rangeland Research Program and the NRCS Conservation Effects Assessment Project. We acknowledge support from the Nevada Agricultural Experiment Station, the Joint Fire Science Program, through SageSTEP, and the USDA Agricultural Research Service's Area-wide Pest Management Program for Annual Grasses in the Great Basin Ecosystem. USDA is an equal opportunity provider and employer.

\section{REFERENCES}

Balch, J.K., B.A. Bradley, C.M. D'Antonio and J. Gomez-Dans. 2013. Introduced annual grass increases regional fire activity across the arid western USA (1980-2009). Global Change Biology 19:173-83.

Bestelmeyer, B.T., and D.D. Briske. 2012. Grand challenges for resilience-based management of rangelands. Rangeland Ecology and Management 65:654-663.

Bestelmeyer, B.T., A.J.Tugel, G.L. Peacock Jr, D.G. Robinett, P.L. Shaver, J.R. Brown, J.E. Herrick, H. Sanchez, and K.M. Havstad. 2009. State-andtransition models for heterogeneous landscapes: A strategy for development and application. Rangeland Ecology and Management 62:1-15.

Brown, J. R. 2010. Ecological sites: Their history, status, and future. Rangelands 32:5-8.

Chambers, J.C., B.B. Bradley, C.S. Brown, C.D. D’Antiono, M.J. Germino, J.B. Grace, S.P. Hardegree, R. F. Miller, and D.A. Pyke. 2013. Resilience to stress and disturbance, and resistance to Bromus tectorum L. Invasion in Cold Desert shrublands of western North America. Ecosystems, doi: 10.1007/s10021-013-9725-5.

Davenport, D.W., D.D. Breshears, B.P. Wilcox, and C.D. Allen. 1998. Viewpoint: Sustainability of piñon-juniper ecosystems - A unifying perspective of soil erosion thresholds. Journal of Range Management 51:231-240.

Doering, O.C., D.J. Lawrence, and J.D. Helmsa. 2013. Agricultural conservation and environmental programs: The challenge of data-driven conservation. Choices 28:1-5.

Dyksterhuis, E.J. 1949. Condition and management of range land based on quantative ecology. Journal of Range Management 2:104-115.

Epanchin-Niell, R., J. Englin, and D. Nalle. 2009. Investing in rangeland restoration in the Arid West, USA: Countering the effects of an invasive weed on the long-term fire cycle. Journal of Environmental Management 91:370-379.

Hernandez, M., M.A. Nearing, J.J. Stone, F.B. Pierson, H. Wei, K.E. Spaeth, P.H. Heilman, M.A. Weltz, and D.C. Goodrich. 2013. Application of a rangeland soil erosion model using National Resources Inventory data in southeastern Arizona. Journal of Soil and Water Conservation 68(6):512-525, doi:10.2489/jswc.68.6.512.

Limbach, E. 2011. Wyoming Sagebrush Steppe. In Fire Effects Information System. Ft. Collins, CO. USDA Forest Service, Rocky Mountain Research Station, Fire Sciences.

Major, D.J., A.R. Sands, and D. Tart. 2011. Mountain Big Sagebrush with Conifers. In Fire Effects Information System. USDA Forest Service, Rocky Mountain Research Station, Fire Sciences Laboratory (Producer). http://www.fs.fed.us/database/feis.

Meyer, G.A., J.L. Pierce, S.H. Wood, and A.J.T. Jull. 2001. Fire, storms, and erosional events in the Idaho batholith. Hydrological Processes 15:3025-3038.

Miller, R.F., J. Chambers, D.A. Pyke, F.B. Pierson, and C.J. Williams. 2013. A review of fire effects on vegetation and soils in the Great Basin Region: Response and ecological site characteristics. General Technical Report RMRS-GTR-308. Fort Collins, CO: USDA Forest Service, Rocky Mountain Research Station.

Miller, R.F., S.T. Knick, D.A. Pyke, C.W. Meinke, S.E. Hanser, M.J. Wisdom, and A.L. Hild. 2011. Characteristics of sagebrush habitats and limitations to long-term conservation. In Greater Sage-Grouse: Ecology and Conservation of a Landscape Species and its Habitats. Studies in Avian Biology (vol.
38), eds. S. T. Knick and J. W. Connelly, 145-184. Berkeley, CA: University of California Press.

Miller, R.F., R.J. Tausch, D.E. McArthur, D. Johnson, and S.C.Sanderson. 2008. Development of Post Settlement Pinyon-Juniper Woodlands in the Intermountain West: A Regional Perspective. Research Paper RMRS-RP-69. Fort Collins, CO: USDA Forest Service, Rocky Mountain Research Station.

Nearing, M.A., H. Wei, J.J. Stone, F.B. Pierson, K.E. Spaeth, M.A. Weltz, and D.C. Flanagan. 2011. A Rangeland Hydrology and Erosion Model. Transaction of American Society of Agricultural and Biological Engineers 54:1-8.

Nicks, A.D., L.J. Lane, and G.A. Gander. 1995. Chapter 2, weather generator. In USDA-Water Erosion Prediction Project: Hillslope Profile and Watershed Model Documentation, eds. D.C. Flanagan and M.A. Nearing , 2.1-2.22. West Lafayette, IN: USDA Agricultural Research Service.

Pellant, M., B. Abbey, and S. Karl. 2004. Restoring the Great Basin desert, USA: Integrating science, management, and people. Environmental Monitoring and Assessment 99:16-179.

Pellant, M., P. Shaver, D.A. Pyke, and J.E. Herrick. 2005. Interpreting indicators of rangeland health, Version 4. Technical Reference 1734-6. Denver, CO: US Department of the Interior, Bureau of Land Management, National Science andTechnology Center. Pierson, F.B., C.J. Williams, S.P. Hardegree, P.E. Clark, P.K. Kormos, and O.Z.Al-Mandan. 2013. Hydrologic and erosion responses of sagebrush steppe following juniper encroachment, wildfire, and tree cutting. Journal of Rangeland Ecology and Management 66:274-289.

Pierson, F.B., C.J. Williams, S.P. Hardegree, M.A.Weltz, J.J. Stone, and P.E. Clark. 2011. Fire, plant invasions, and erosion events on western rangelands. Rangeland Ecology and Management 64:439-449.

Romme,W.H., C.D.Allen, J.D. Balley, W.L. Baker, B.T. Bestelmeyer, P.M. Brown, K.S. Eisenhart, M.L. Floyd, D.W. Huffman, B.F. Jacobs, R.F. Miller, E.H. Muldavin, T.W. Swetnam, R.J. Tausch, and P.J. Weisberg. 2009. Historical and modern disturbance regimes, stand Structures, and landscape dynamics in pinon-juniper vegetation of the Western United States. Rangeland Ecology and Management 62:203-222.

Running, S.W. 2006. Is global warming causing more, larger wildfires? Science 313:927-928.

Stockmann, K., J. Burchfield, D. Calkin, and T. Venn. 2010. Guiding preventative wildland fire mitigation policy and decisions with an economic modeling system. Forest Policy and Economics 12:147-154.

Taylor, M.H., K. Rollins, M. Kobayashi, and R.J.Tausch. 2013. The economics of fuel management:Wildfire, invasive plants, and the dynamics of sagebrush rangelands in the Western United States. Journal of Environmental Management 126:157-173.

Tidwell, D., B.W. Allred, and S.D. Fuhlendorf. 2013. National-scale assessment of ecological content in the world's largest land management framework. Ecosphere 48:1-27.

Weltz, M., and K. Spaeth. 2012. Estimating effects of targeted conservation on nonfederal rangelands. Rangelands 34:35-40.

Wilcox, B.P., L. Turnbull, M.H. Young, C.J. Williams, S.Ravi, M.S. Seyfried, D.R Bowling, R.L. Scott, M.J. Germino, T.G. Caldwell, and J. Wainwright. 2012. Invasion of shrublands by exotic grasses: Ecohydrological consequences in cold versus warm deserts. Ecohydrology 5:160-173. 